\title{
Et poetologisk magtskifte
}

Michael Kallesøe Schmidt: Forfatterpoetik: En genres historie. Forlaget Spring 2018, 360 sider.

Michael Kallesøe Schmidts bog Forfatterpoetik: En genres historie, som bygger på hans ph.d.-afhandling, er en ambitiøs tour de force gennem den danske poetikhistorie. En historie, som i bogen starter med Paul la Cours Fragmenter af en dagbog (1948) og slutter med Christian Stokbro Karlsens Poetik (2017). Undervejs berøres gamle kendinge i poetikforskningen såsom Per Højholts Cézannes Metode (1967) og Søren Ulrik Thomsens Mit lys brænder (1985), men mindre kanoniserede poetikker får også en plads i Schmidts genrehistorie - for eksempel Henrik Bjelkes Seks råb fra baghovedet (1981) og Finn Barlby og Marianne Larsens SIMSALABIM (2006). Ingen af værkerne er dog helt ukendte eller oversete i litteraturforskningen, og Schmidt gør det også fra begyndelsen klart, at han vil fokusere på de mest kanoniserede værker i poetikforskningen. Formålet er ikke så meget at finkæmme det poetologiske arkiv for at finde hidtil negligeret materiale, som det er at sætte den allerede etablerede poetikkanon i system og skabe et historisk overblik over genren: "Højest prioritet i afhandlingen har den kronologiske gennemgang af forfatterpoetikker fra Fragmenter af en Dagbog frem til nutiden" (s. 12).

Som det fremgår af citatet ovenfor, introducerer Schmidt med sin afhandling en ny genrebetegnelse, "forfatterpoetik". Det er også titlen på bogen. Med denne nye genrebetegnelse ønsker han én gang for alle at indkredse det kendetegnende ved skønlitterære forfatteres refleksioner over det at skrive, og hvordan de adskiller sig fra for eksempel den akademiske afhandling om poetologiske spørgsmål, som almindeligvis også hører hjemme under paraplybetegnelsen "poetik". Schmidt medgiver selv, at den litteraturvidenskabelige tendens til at sammensætte nye begreber kan være tvivlsom, men det er samtidig svært at se sig sur på hans nye genrebetegnelse. Det er en nyttig præcisering, og den er, som han selv skriver, rimelig indlysende: “Det simple kompositum 'forfatterpoetik' forklarer da næsten også sig selv: poetik skrevet af forfattere" (s. 11). For at blive betegnet som forfatterpoetik skal et værk leve op til en række genrekriterier, vigtigst, at det retorisk er kendetegnet ved selvrefleksion. Det lyder enkelt nok, men denne selvrefleksivitet kan antage mange former og omgive sig med alt fra lyrik til filosofi. Gennem bogen bliver man hele tiden mindet om, hvor sammensat og besynderlig forfatterpoetikken som genre egentlig er. 
Allerede i forordet fremlægger Schmidt de fire centrale spørgsmål, som afhandlingen søger at besvare: "1) Hvad er forfatterpoetik? 2) Hvordan lader forfatterpoetik sig beskrive som genre? 3) Hvordan opstod genren i dansk litteratur? 4) Hvordan har genren udviklet sig?" (s. 11). Han argumenterer undervejs flere gange for, at afhandlingens arbejde er motiveret af en grundlæggende uenighed om, hvordan genren poetik skal defineres i litteraturforskningen. Der er nogenlunde konsensus om, hvilke værker, der er kanoniske og eksemplariske for genren, men ikke så meget om de kriterier et værk skal opfylde for at blive betegnet som en poetik: "Med andre ord opererer dansk litteraturforskning med en bredt accepteret poetikkanon, hvis generiske karakteristika den endnu ikke har beskrevet tilfredsstillende" (s. 22). Det er dette genreteoretiske udgangspunkt, som giver hans undersøgelse en frisk toning i et ellers velbesøgt forskningsområde, og med Schmidts ord tegner en "tredje vej" mellem filosofiske og mere forfatterskabsorienterede poetiklæsninger (s. 340).

Bogens struktur og værkanalyserne bærer ikke så overraskende præg af Schmidts prioritering af den kronologiske gennemgang af forfatterpoetikkerne. Det har sine analytiske ulemper med sådan en kronologisk værkgennemgang, men fordelen ved afhandlingens relativt lange penselstrøg er, at der kommer slægtskaber imellem værkerne til syne, som man bedst kan se fra dette metodiske ståsted. For eksempel når Schmidt overbevisende sporer fragmentets stilistiske indflydelse på forfatterpoetikken som genre i Danmark tilbage til la Cour (og dermed den franske lyriker Pierre Reverdy), eller når han fremhæver tilfældigheden som et tema i beskrivelsen af skriveprocessen hos forfattere som Per Højholt og Inger Christensen og fremefter. Analyserne står stærkest, når den slags stilistiske og tematiske forbindelseslinjer sættes i relief, og når Schmidt for en stund gør holdt i sin odyssé gennem poetikhistorien for analytisk at dvæle ved et poetologisk tema, en stilistisk detalje, et konkret citat. Det er desuden med til at forstærke afhandlingens relevans, at den medtager poetikker fra samtidige indflydelsesrige forfattere som blandt andre Mikkel Thykier og Amalie Smith. Og så må man bare sige, at Schmidts afhandling set som videnskabeligt rugbrødsarbejde er beundringsværdig. Jeg forestiller mig, at den vil fungere som støttehjul for flere fremtidige undersøgelser af forfatterpoetikkens fascinerende væsen.

I et afsluttende kapitel om afhandlingens blinde vinkler nævner Schmidt selv begrænsningerne i sin genreafgrænsning. Der er ret beset mange (også forskningsmæssigt) interessante poetologiske tekster, som ikke lever op til Schmidts kriterier, som blandt andet indbefatter, at værket skal have været udgivet i bogform i forfatterens samtid. En afgrænsning af materialet er dog altid nødvendig, og det tjener Schmidt til ære, at han undervejs i afhandlingen inkluderer en hel del poetiktekster, som ikke kvalificerer sig til hans genrebetegnelse. Selvom formålet er at skitsere en sammenhængende, afgrænset genrehistorie, er der i analyserne stadig plads til de tekster, som på forskellige måder falder uden for, men alligevel synes vigtige, og som illustrerer poetikgenrens alsidighed. Et eksempel på en sådan "ukvalificeret" tekst er BrobyJohansens "Forsvarstale for BLOD" (1923), som Schmidt i begyndelsen hiver ind for at illustrere afhandlingens metode. Ud over de generiske begrænsninger erkender Schmidt, at undersøgelsen med fordel også kunne have antaget en bredere tidsramme, et internationalt perspektiv samt et blik for værkernes sociologiske kontekst. 
Efter min mening gemmer en af afhandlingens mest interessante pointer sig i overgangen mellem bogens redegørende og analytiske del, hvor han knytter en kommentar til det historiske skift fra akademiske poetikafhandlinger til forfatterpoetikker:

64 Forandringen i poetikopfattelsen inden for akademia og skønlitteratur indebærer ganske enkelt et poetologisk magtskifte. Vejen fra disciplin til genre medfører en interesseforskydning fra akademikernes poetik til forfatternes poetik. Og forfatterpoetikken har en rækkevidde, som den her skitserede akademiske poetiktradition aldrig ville kunne få. (s. 96)

Jeg håbede på, at Schmidt senere i bogen ville vende tilbage til denne pointe, da den for mig at se italesætter en af de øjenåbnende virkninger ved at anlægge et genreperspektiv på poetikker. Schmidts genrehistorie viser, hvordan fremkomsten af forfatterpoetikken som genre overdrog skønlitterære forfattere den autoritet til at udtale sig om litterære tilblivelsesprocesser, som vi kender fra i dag. Der er lang vej fra den opmærksomhed, vi nu tildeler skønlitterære forfatteres blogopslag, Facebook-opdateringer og interviews i forskellige medier, og den mere skeptiske opfattelse af forfatterens indsigt i sit eget arbejde, som litteraturprofessoren Paul Rubow i bogens forord fremstår som en repræsentant for: "Men hvor mange digtere har egentlig forstaaet at meddele den litterære kendsgerning, sige de ord om deres egne frembringelser, som i strengeste Forstand kommer sagen ved?" (s. 13).

Jeg forestiller mig, at vi i dag er vidne til nogle af virkningerne af dette poetologiske magtskifte, hvor skønlitterære forfattere betragtes som specialister i litteratur, og hvor den kreative skriveproces anerkendes som en frugtbar erkendelsesform. I de senere år har der været en stigende interesse i forskningsområder, som på forskellige måder omhandler litterær tilblivelse: Genetisk kritik er en af dem, praksisbaseret forskning i kreativ skrivning en anden, forskning i forfatterpoetikker en helt tredje. Der er mange flere eksempler, og de er forbundne af deres interesse for tilblivelsesprocessen. Det sker oftere og oftere, at en litteraturforsker interviewer en skønlitterær forfatter om vedkommendes tanker med sit værk, fordi de faktisk forstår at meddele den litterære kendsgerning. Samtidig er der sket en opblomstring af forfatterskoler og kreative skrivekurser - også på universitetet. På den måde skal man ikke kun se Forfatterpoetik: En genres historie som et isoleret bidrag til dansk poetikforskning, men også som en del af en stadigt voksende interesse for, hvordan litteratur bliver til - og hvordan vi griber det spørgsmål an i litteraturforskningen. Schmidts afhandling er en brugbar oversigt til dem, som studerer forfatteres refleksioner over litteratur og det at skrive.

Anmeldt af Hans Lind 